\title{
FAKTOR YANG MENYEBABKAN PETANI KEMIRI BERUBAH MENJADI PETANI KAKAO DI DESA KUBU KECAMATAN LAWE ALAS KABUPATEN ACEH TENGGARA \\ Oleh :
}

\author{
Supriadi* \\ Mbina Pinem**
}

\begin{abstract}
Abstrak
Penelitian ini bertujuan untuk mengetahui faktor yang menyebabkan petani kemiri berubah menjadi petani kakao dilihat dari 1). Pengalaman dan pendidikan, 2). Modal, 3). Harga, 4). Pendapatan. Penelitian ini dilakukan di Desa Kubu Kecamatan Lawe Alas Kabupaten Aceh Tenggara. Populasi dalam penelitian ini adalah seluruh petani kemiri yang berubah menjadi petani kakao dengan jumlah 100 Kepala Keluarga dan sampel yang diambil $50 \%$ yaitu sebanyak 50 kepala keluarga yang diambil secara proporsional random sampling. Teknik pengumpulan data adalah komunikasi langsung dan alat pengumpul data adalah dengan menggunakan angket. Teknik analisa data yang digunakan adalah analisa data diskriptif kualitatif. Hasil yang diperoleh dalam penelitian ini adalah : (1). Pengalaman yang dimiliki petani kakao sudah cukup baik artinya pengetahuan petani kakao dalam mengolah lahan tanaman kakao mulai dari pembibitan sampai awal panen. (2). Modal yang dibutuhkan petani kakao lebih banyak daripada petani kemiri yaitu sebesar Rp. $600.000-$ Rp. 2.600.000, sedangkan modal petani kemiri sebesar Rp. 35.000 - Rp. 96.700. (3). Faktor yang paling dominan yang menyebabkan petani kemiri berubah menjadi petani kakao adalah harga kakao lebih menguntungkan. (4). Pendapatan petani kakao lebih tinggi daripada petani kemiri. Pendapatan petani kakao sebesar Rp. 600.000 - Rp. 1.520.000/bulan. Sedangkan pendapatan petani kemiri sebesar Rp. 180.000 - Rp. 236.700/bulan
\end{abstract}

Kata Kunci: Faktor, Petani Kemiri, Kakao

\section{A. Pendahuluan}

Kepala Dishutbun Aceh Tenggara, Ir. M. Sragafa, M.Pd., mengakui adanya fenomena pergeseran. Kebutuhan biji kemiri di pasar sangat sedikit karena kebanyakan hanya digunakan untuk bumbu masakan dan minyak rambut. Sekarang produksi tanaman kemiri merosot drastis dari sebelumnya sekitar 9.000 ton sekarang menjadi 6.000 ton/tahun. Melihat dari fenomena tersebut niat pemerintah Aceh yang akan menjadikan kemiri Agara sebagai komoditas ekspor andalan sepertinya bakal percuma, kalau rencana tersebut terlalu lama terealisasi, bukan tidak mungkin,

\footnotetext{
${ }^{*}$ Alumni Jurusan Pendidikan Geografi, Fakultas Ilmu Sosial, UNIMED

** Dosen Jurusan Pendidikan Geografi, Fakultas Ilmu Sosial, UNIMED
} 
ketika dilakukan ekspor sudah tidak ada lagi hasil kemiri yang bisa diekspor dari Agara karena produksi tanaman kemiri merosot drastis.

Permasalahan pokok pengembangan kemiri belum terwujudnya ragam, kualitas, kesinambungan pasokan, dan kuantitas yang sesuai dengan dinamika permintaan pasar, permasalahan tersebut nampak nyata pada produk hortikultura untuk tujuan pasar konsumen institusi dan ekspor. Permasalahan lain adalah ketimpangan dalam penguasaan ilmu pengetahuan dan teknologi, asset utama lahan, modal, dan akses pasar antar pelaku agribisnis menyebabkan struktur kelembagaan kemitraan usaha pada komoditas kemiri yang terserang oleh hama sehingga mengakibatkan pembusukan daun, bunga dan batang.

Di Desa Kubu banyak masyarakat yang tidak mengerti tentang budidaya tanaman kemiri, sehingga usaha taninya tidak berkembang, dan banyak masyarakat yang mengikuti metode yang berasal dari orang tua mereka atau meniru sesuatu dari tetangganya. Perawatan tanaman yang utama seperti pemupukan dan pemberantasan gulma jarang dilakukan karena, kurangnya pengalaman dan pendidikan dalam mengelola tanaman kemiri sehingga dapat diketahui bahwa pendidikan sangat berkaitan erat dengan pertanian sehingga masyarakat membutuhkan pendidikan atau pengalaman dalam mengolah tanaman kemiri.

Modal merupakan faktor utama dalam suatu usaha termasuk juga usaha pertanian tanaman kemiri dan tanaman kakao, karena modal merupakan faktor utama dalam melaksanakan dan mengembangkan hasil pertanian. Jika tidak ada modal maka usaha untuk pengolahan lahan pertanian dalam memperoleh produksi tidak akan tercapai dan usaha pertanian mustahil dapat dilakukan. Budidaya tanaman kemiri tidak membutuhkan biaya tinggi karena tidak banyak memerlukan perawatan khusus, umumnya di tingkat petani tanaman kemiri dibudidayakan di lahan-lahan kritis. Pemberian pupuk kandang akan menjadikan tanaman kemiri tumbuh lebih cepat dan mempunyai peluang untuk menghasilkan kemiri yang lebih baik.

Produksi yang semaksimal mungkin merupakan dambaan dari setiap petani, karena dengan tingginya produksi yang diperoleh dari usaha tani, maka akan meningkatkan pendapatan keluarga. Tingkat kehidupan petani sangat ditentukan pada hasil tanaman yang mereka peroleh. Jumlah hasil produksi kemiri menurun disebabkan oleh harga kemiri tidak stabil (turunnya harga), banyak hama yang menyerang tanaman kemiri sehingga tanaman kemiri kurang modal dan kurang mengerti tengtang budidaya kemiri, dan perawatan kurang mengerti. Sehingga 
kehidupan mereka tidak sesuai dengan penghasilan dan kadangkadang tidak mencukupi kebutuhan keluarga mereka. Dengan demikian masyarakat di Desa Kubu banyak mengangantikan tanaman kemiri menjadi tanaman kakao.

Tanaman kemiri merupakan hasil pertanian yang sudah tidak asing lagi di Desa Kubu, hampir seluruh masyarakat di Desa Kubu berpenghasilan dari tanaman kemiri. Akan tetapi beberapa akhir tahun yang lalu masyarakat mengagantikan tanaman kemiri menjadi tanaman kakao. Setengah penduduk Desa Kubu Kecamatan Lawe Alas Kabupaten Aceh Tenggara menanam kakao menggantikan tanaman kemiri menjadi tanaman kakao. Masalah ini ditinjau dari : (1) harga kakao lebih tinggi daripada harga kemiri, (2) cara perawatan kakao lebih sulit dari pada tanaman kemiri apalagi pemupukan pada kakao dilakukan dengan dosis yang tepat maka kakao akan tumbuh subur dan menghasilkan buah kakao yang banyak, (3) mengambil hasil kakao lebih cepat daripada mengambil hasil kemiri, karena kakao dapat dipanen 2 kali seminggu dalam jangka waktu 1 tahun pada musim buahnya, (4) harga kakao lebih stabil dari pada kemiri, (5) lebih tinggi pendapatan dari hasil kakao dari pada kemiri, (6) meningkatnya harga pupuk dan obat-obatan pada tanaman.

Melihat dari kenyataan tersebut, maka penulis sangat tertarik untuk meneliti faktor yang menyebabkan perubahan tanaman kemiri menjadi kakao di Desa Kubu Kecamatan Lawe Alas Kabupaten Aceh Tenggara.

Adapun yang menjadi tujuan penelitian ini adalah : 1) Untuk mengetahui pengalaman atau pendidikan yang menyebabkan petani kemiri berubah menjadi petani kakao di Desa Kubu Kecamatan Lawe Alas Kabupaten Aceh Tenggara, 2)Untuk mengetahui modal yang menyebabkan petani kemiri berubah menjadi petani kakao di Desa Kubu Kecamatan Lawe Alas Kabupaten Aceh Tenggara, 3) Untuk mengetahui keadaan harga dari penjuanlan kakao yang dimiliki petani kakao yang menyebabkan petani kemiri berubah menjadi petani kakao di Desa Kubu Kecamatan Lawe Alas Kabupaten Aceh Tenggara, 4) Untuk mengetahui besarnya pendapatan yang diperoleh petani kakao dari hasil penjualan kakao di Desa Kubu Kecamatan Lawe Alas Kabupaten Aceh Tenggara

\section{B. Metodologi Penelitian}

Dalam pengumpulan data maka penulis memilih lokasi penelitian di Desa Kubu Kecamatan Lawe Alas Kabupaten Aceh Tenggara. Lokasi ini dipilih dengan pertimbangan antara lain : (1) Desa Kubu Kecamatan Lawe Alas Kabupaten Aceh Tenggara 
sudah banyak petani yang merubah tanaman kemiri berubah menjadi tanaman kakao. (2) Sejauh pengamatan penulis penelitian dengan objek yang diteliti di Desa Kubu Kecamatan Lawe Alas Kabupaten Aceh Tenggara belum pernah dilakukan penelitian yang sama. (3) Ingin melihat secara langsung keberadaan petani yang merubah tanaman kemiri menjadi tanaman kakao di Desa Kubu Kecamatan Lawe Alas Kabupaten Aceh Tenggara.

Adapun yang menjadi populasi dalam penelitian ini adalah seluruh masyarakat petani kemiri yang berubah menjadi petani kakao di Desa Kubu Kecamatan Lawe Alas Kabupaten Aceh Tenggara dari tahun 2006-2010 yang berjumlah 100 KK (kepala keluarga) dan umur kakao sudah berumur 3 tahun setelah ditanam dalam artian tanaman kakao sudah berproduksi.

Sampel yang diambil dalam penelitian ini adalah yang terdiri dari 1 desa mempunyai 3 dusun dan tiap dusun diambil 50 $\%$ sehingga sampel penelitin ini berjumlah $50 \mathrm{KK}$ (kepala keluarga). Dalam pengambilan ini dilakukan secara proporsional random sampling. Adapun yang menjadi variable penelitian ini adalah pengalaman, pendidikan, modal, harga dan pendapatan.

Variable-variabel yang akan dianalisis memerlukan defenisi operasional sebagai berikut : 1) Pengalaman adalah merupakan dasar petani dalam menentukan suatu jenis tanaman yang diusahainya atau yang dikelola oleh petani dan mempunyai kebiasaan-kebiasaan petani yang selalu bertanya jenis tanaman yang lebih menguntungkan baginya dan perawatannya yang sederhana dan mudah. 2) Pendidikan yang dimaksud adalah pendidikan pendidikan non formal yaitu pendidikan atau pengetahuan keterampilan yang diberikan oleh kedua orang tua (orang lain) kepada anak baik dalam keluarga maupun lingkungan hidupnya tanpa mengeluarkan biaya pendidikan. 3) Modal adalah keseluruhan jumlah dana atau materi yang digunakan usaha tani, mulai dari awal pengelolaan sampai akhir pengelolaan yang mencakup bibit atau benih, pupuk dan pestisida dan lain-lain. 4) Harga adalah ukuran nilai barang dan jasa atau ukuran nilai ekonomi yang dimiliki suatu barang berupa satuan uang untuk hasil penjualan kakao. 5) Pendapatan adalah pendapatan diperoleh petani dan produksi kopi pendekatan ini yang dilakukan dengan menghitung seluruh penghasilan yang diperoleh petani kakao setiap bulannya kemudian dikurangi biaya operasional.

Alat pengumpulan data yang digunakan pada penelitian ini adalah : 1) Teknik Komunikasi Langsung yaitu peneliti mengajukan pertanyaan-pertanyaan secara lisan kepada responden sehingga dapat memberikan informasi yang tepat tentang objek yang diteliti. 2) Angket adalah salah satu cara yang dilakukan 
untuk memperoleh data penelitian (data primer) dengan memberi sejumlah pertanyaan yang disusun secara sistematis kemudian dibagikan kepada setiap responden untuk dijawab. Selanjutnya dikumpulkan untuk diolah sesuai dengan tujuan penelitian.

Hasil penelitian ini akan dianalisis secara deskriptif kualitatif yaitu penelitian mendeskripsikan kenyataan yang ada dilapangan dan dibuat kedalam tabel-tabel frekuensi dan selanjutnya dicari kesimpulan yang dianggap penting.

\section{Pembahasan}

Dalam penelitian ini disajikan hasil pengolahan data yang diperoleh dari lapangan, urutan pembahasan disesuaikan dengan tujuan penelitian yaitu untuk megetahui faktor yang menyebabkan petani kemiri berubah menjadi petani kakao di Desa Kubu Kecamatan Lawe Alas Kabupaten Aceh Tenggara yakni pengalaman atau pendidikan, modal, harga dan pendapatan.

\section{Pengetahuan dan Pendidikan}

Berdasarkan jawaban petani dapat diketahui bahwa pengalaman untuk menanam kakao lebih banyak yang berpengalaman dan sudah cukup lama yaitu sekitar $3-4$ tahun dan jumlah petani yang berubah dari petani kemiri menjadi petani kakao ada sebanyak 28 petani (56\%). Sedangkan dilihat dari pendidikannya petani kakao memiliki pendidikan yang sangat rendah karena pendidikannya yang didapat petani yang paling banyak adalah didapat dari penyuluhan pertanian yaitu sebanyak 28 petani $(56 \%)$. Untuk merawat tanaman kakao agar hasilnya lebih baik, cara yang paling banyak yaitu memilih dengan melakukan pemangkasan. Berdasarkan alasan petani menyatakan bahwa apabila dilakukan pemangkasan dengan teratur dan tepat maka hasil produksi kakao semakin meningkat. Jadi hal ini dapat dilihat bahwa petani mendapat pengalaman dari penyuluhan pertanian sementara pendidikan petani tentang menanam kakao masih rendah, akan tetapi petani kakao lebih mengutamakan pengalaman dalam mengolah tanaman kakao dari pada pendidikan petani karena pengalaman berpengaruh terhadap peningkatan produksi kakao yang dihasilkan.

\section{Modal}

Pada umumnya masyarakat pedesaan yang menjadi petani hidup dalam keadaan miskin. Dengan demikian modal yang dimiliki pun sedikit yang mengakibatkan teknik peralatan dan perlengkapan yang digunakan masih tergolong sederhana. Dengan berbagai barang modal yang berteknologi rendah itu tentu saja tidak akan menghasilkan hasil pertanian yang besar. Modal usahatani dalam arti mikro adalah faktor produksi modal yang 
disediakan, diolah dan dikontrol di dalam suatu usahatani. Modal dapat berupa modal investasi dan modal operasional. Penggunaan modal tersebut bertujuan agar usahatani dapat berjalan dan berproduksi untuk meningkatkan kesejahteraan masyarakat khususnya masyarakat tani.

Dalam memanfaatkan modal sebagai biaya sangat mempengaruhi petani dalam mengembangkan tanaman kakaonya, hal ini disebabkan karena mempunyai nilai ekonomi yang harus dikeluarkan untuk memperoleh hasil, misalnya 1) pembelian bibit, 2) pembelian pupuk, 3) pembelian pestisida, 4) upah tenaga kerja, 5) membeli alat.

\section{Pembelian Bibit}

Berdasarkan hasil angket yang telah disebarkan kepada semua petani kakao di Desa Kubu mengalokasikan modal untuk bibit yaitu dapat dilihat pada tabel 20 yaitu sebanyak 35 petani (70 $\%)$. Petani lebih banyak memilih bibit dari penjual bibit yang dipesan, alasan petani karena bibitnya lebih terjamin dan cepat tumbuh. Berdasarkan wawancara dengan masyarakat bahwa harga bibit kakao yang dibeli dari penjual bibit yang dipesan adalah sebesar Rp. 1.000/batang. Adapun jarak tanaman kakao yaitu 3 x 3 meter.

\section{Pembelian Pupuk}

Unsur hara merupakan unsur yang paling dibutuhkan oleh tanaman kakao, untuk pertumbuhan batang, daun, cabang baru, bunga dan buah. Apabila tanaman kekurangan unsur hara maka menimbulkan gejala-gejala yang merugikan seperti tanaman kakao menjadi kurus, daun menguning sehingga terjadi keguguran daun dan tanaman sulit berbuah. Untuk itu perlu ditambahkan unsur hara kedalam tanah karena unsur hara sangat penting dan dibutuhkan oleh tanaman kakao seperti pupuk ORGANIK GRANUL, NPK dan pupuk kandang. Tujuan pemberian pupuk ini adalah untuk memperbaiki mutu tanah agar tanah menjadi gembur, perkembangan akar baik, membantu pertubuhan batang, membantu perkembangan bunga dan mempercepat pemasakan buah.

Pemberian pupuk pada tanaman kakao biasanya dilakukan petani di Desa Kubu 2 kali dalam satu tahun. Pemberian pupuk pertama diberikan ketika tanaman kakao belum berbunga dan diawal penanaman, pupuk yang dibutuhkan adalah pupuk ORGANIK GRANUL sebanyak $350 \mathrm{~kg} /$ hektar dan setiap batang pohon kakao diberi pupuk sebanyak 500 gram/ batang. Pemupukan yang kedua dilakukan setelah berbunga, pupuk yang dibutuhkan pupuk NPK sebanyak $350 \mathrm{~kg} /$ hektar dan setiap batang diberi pupuk sebanyak 500 gram/batang. Berdasarkan tabel 23 
modal petani untuk pembelian pupuk ada sebesar Rp. $200.000-$ Rp. 600.000, yaitu sebanyak 24 petani (48\%).

\section{Pembelian Pestisida}

Berdasarkan wawancara dengan masyarakat, tanaman kakao tahan terhadap serangan hama atau jarang terkena penyakit. Oleh sebab itu apabila petani menggunakan pestisida itu digunakan untuk memberantas rumput disekitar batang kakao.

\section{Tenaga Kerja}

Tenaga kerja yang paling banyak digunakan di Desa Kubu adalah tenaga kerja dari luar (tenaga kerja yang diupahkan) yaitu sebanyak 31 petani $(62 \%)$ sedangkan tenaga kerja dari anggota keluarga sebanyak 19 petani (38 \%). Dari jawaban responden bahwa petani lebih mengutamakan tenaga kerja yang berasal dari luar (tenaga kerja yang diupahkan) dengan tujuan agar lebih mudah untuk megolah tanaman kakao artinya dalam pengolahan lahan kakao tersebut harus menyediakan modal untuk upah tenaga kerja supaya hasil tanaman kakao sangat memuaskan. Pada tabel 25 Besarnya Modal Yang Dibutuhkan Kakao Untuk Tenaga Kerja yaitu sebesar Rp. 500.000 - Rp. 1.000.000. ini biasanya petani yang kekurangan tenaga kerja dari kelurga sendiri sehingga lahan dapat diolah dengan baik, upah tenaga kerja yang diupahkan yaitu sebesar Rp. 30.000/orang dalam satu hari.

\section{Beli Alat}

Dalam penggunaan alat pertanian kakao di Desa Kubu masih menggunakan peralatan tradisional yaitu parang, cangkol dan gunting, sementara itu menggunakan mesin sinso bagi mereka yang mengolah lahan pada saat melakukan penebangan pokok kemiri untuk dijadikan tanaman kakao. Modal yang dikeluarkan untuk membeli alat pada tabel 26 dapat dilihat modal yang dibutuhkan tanaman kakao untuk beli alat yaitu sebesar Rp. 100.000 - Rp. 200.000 yaitu sebanyak 28 petani (56\%) dan yang paling sedikit sebanyak 8 petani $(16 \%)$ yaitu sebesar Rp. 310.000 - Rp. 400.000.

Modal yang dibutuhkan untuk tanaman kakao dapat dilihat pada tabel 27 yaitu sebesar Rp. 600.000 - Rp. 2.600.000 sebanyak 36 petani $(72 \%)$ modal dari awal menanam sampai panen pertanama dan ini sudah termasuk pemupukan, penyemprotan hama, pestisida dan biaya untuk mengolah lahan atau penunasan dengan cara memakai gunting yang hanya setahun 4 kali , sedangkan modal untuk tanaman kemiri mulai dari menanam sampai awal panen dapat dilihat pada tabel 28 yaitu sebesar Rp. 35.000 - Rp. 96.700 yaitu sebanyak 40 petani (80\%). Modal ini sangat banyak digunakan untuk membeli alat, selain itu modal 
untuk pembelian bibit hanya sedikit karena bibit dapat diperoleh dari tetangga sendiri dibeli dan disemaikan sendiri.

\section{Harga}

Kakao merupakan sebagai bahan makan ringan (Coklat) dan berkhasiat yang mempunyai arti ekonomi yang cukup tinggi bagi para petani. Kakao sangat dikenal masyarakat luas baik didalam negeri maupun diluar negeri. Panen kakao dapat dilakakukan setiap minggu sekali jika pada musimnya kakao dapat dipanen 2 kali dalam satu minggu. Menurut Mubyarto mengemukakan "salah satu gejala ekonomi yang sangat penting yang berhubungan dengan perilaku petani baik sebagai produsen maupun sebagai konsumen adalah harga. Harga diartikan sebagai ukuran dari barang-barang dan jasa".

Dari jawaban petani pada angket menunjukan bahwa faktor harga sebagai alasan utama petani sehingga petani berubah dari petani kemiri menjadi petani kakao. Pada tabel 30 Petani yang menyatakan harga kakao yaitu sebesar Rp. 18.000/kg ada sebanyak 20 petani $(40 \%)$. Sedangkan pada kemiri harganya selalu tidak menentu. Sementara untuk merawat tanaman kemiri sangat kecil modalnya mulai dari pembibitan sampai awal panen.

Berdasarkan jawaban dari petani kenapa memilih petani kakao dari pada petani kemiri karena harga kakao jarang naik turun (stabil) dan harganya dapat terjamin atau tidak sama sekali merugikan jika tanaman kakao dapat diolah dengan baik. Sedangkan untuk tanaman kemiri hanya membutuhkan modal yang sedikit, pendapatan sedikit karena harga kemiri lebih sedikit dengan harga hasil tanaman kakao. Untuk tanaman kakao lebih sulit mengolahnya dan apabila dilakukan dengan pemupukan yang sesuai dengan dosisnya sehingga dapat meningkatkan produksinya dan berpengaruh terhadap pendapatan, pendapatan juga semakin meningkat apabila didukung oleh harga kakao yang tinggi.

\section{Pendapatan}

Pendapatan adalah seluruh penerimaan berupa uang atau barang baik dari usaha sendiri ataupun usaha dari pihak lain dengan jalan dinilai dari seluruh uang atas harga yang berlaku pada saat itu. Secara teori pengertian pendapatan tergantung darimana orang memandang, pada dasarnya pendapatan diperoleh dari penjualan barang dan pemberian jasa yang dihitung dalam uang rupiah yang diperoleh dari setiap bulannya (Sumardi, 1982). Pada petani kakao apabila pada musim bunga maka pertanian tersebut dapat memetik hasil kakao sebanyak 2 kali dalam satu minggu sehingga mempengaruhi pendapatan. Dari jawaban petani pada tabel 32 dapat dijelaskan bahwa pendapatan petani sebesar Rp. 600.000 - Rp. 1.520.000/bulan yaitu sebanyak 38 petani (76 
\%). Dari pengakuan petani selama petani berubah dari petani kemiri menjadi petani kakao pendapatan atau penghasilannya semakin meningkat dibandingkan dengan menanam tanaman kemiri. Sedangkan pendapatan petani kemiri sangat rendah dibandingkan dengan petani kakao dapat dilihat pada tabel 33 dimana pendapatan sebesar Rp. 180.000 - Rp. 236.700 sebanyak 28 petani $(56 \%)$.

Jika dikaitkan dengan pendapatan sajogyo (1996) yang dikonversi dengan harga beras yaitu sebesar Rp. 6.000/kg pada saat penelitian dilakukan bila dalam satu keluarga 5 orang, yang berjumlah Rp. 1.050.000/bulan maka hasil yang diperoleh dari Upah Minimum Region (UMR) Nanggroe Aceh Darussalam 2010 pendapatan petani kakao juga termasuk lebih cukup dimana Upah Minimum Region Propinsi Nanggroe Aceh Darussalam sebanyak Rp. 1.300.000/bulan.

\section{Kesimpulan Dan Saran}

Berdasarkan hasil penelitian yang dilakukan maka diperoleh kesimpulan sebagai berikut : 1) Pengalaman yang dimiliki petani sudah lumayan baik terlihat dari petani kemiri berubah menjadi petani kakao dari $3-4$ tahun sebanyak 28 petani (56\%) tetapi pendidikan yang dimiliki petani masih rendah pendidikan petani lebih banyak dari pendidikan non formal atau pendidikan dari penyuluhan pertanian sebanyak 28 petani (56\%). 2) Modal juga yang menyebabkan petani kemiri berubah menjadi petani kakao, dimana modal yang dibutuhka oleh petani kakao lebih banyak daripada petani kemiri. Modal yang dibutuhkan petani kakao sebesar Rp. 600.000 - Rp. 2.600 .00036 petani $(72 \%)$ mulai dari penanaman sampai awal panen sedangkan modal yang dibutuhkan petani kemiri sebesar Rp. 35.000 - Rp. 96.700 sebanyak 40 petani $(80 \%)$. 3) Faktor yang paling dominan menyebabkan petani kemiri berubah menjadi petani kakao adalah harga. Dimana harga dari penjualan kakao banyak mempengaruhi petani, sebanyak 24 petani $(48 \%)$. Karena harga kakao lebih terjamin atau stabil daripada harga kemiri, selain terjamin atau stabil harga kakao lebih tinggi daripada kemiri, dibandingkan dengan harga kemiri yang kadang-kadang semakin turun. Harga kakao jarang berfluktasi dan tidak pernah merugikan petani dan harga kakao lebih seimbang dengan modal yang dikeluarkan. 4) Pendapatan petani setelah menjadi petani kakao semakin meningkat daripada petani kemiri, sehingga petani kakao lebih tertarik mempertahankan menanam kakao daripada menanam kemiri kembali. Pendapatan petani kemiri sebelum menjadi petani kakao atau masih petani kemiri sebesar Rp. 180.000 - Rp. 236.700/bulan sebanyak 28 petani (56 
\%) setelah menjadi petani kakao pendapatan sebesar Rp. 600.000 - Rp. 1.520.000/bulan sebanyak 38 petani (76 \%). Hal ini berarti ada peningkatan pendapatan setelah menjadi petani kakao. 5) Lebih sulit merawat tanaman kakao daripada tanaman kemiri, apalagi pada tanaman kakao dilakukan dengan pemberian pupuk sesuai dengan dosisnya sehingga dapat meningkatkan produksi kakao dan meningkatkan pendapatan dibandingkan dengan tanaman kemiri, dimana untuk mengolah kemiri tidak terlalau sulit bahkan ada petani yang hanya membiarkan saja tanpa diolah sehingga hasil produksi kemiri yang diperoleh sangat sedikit.

Saran yang diberikan oleh peneliti adalah sebagai berikut: 1) Melihat secara geografis di Desa Kubu yang sangat mendukung untuk mengolah tanamanan kakao, sehingga perlu adanya dukungan dari pemerintah untuk mendorong masyarakat semakin meningkatkan hasil tanaman kakao. 2) Dilihat dari pendidikan masyarakat yang masih rendah tentang tanaman kakao, agar pemerintah setempat terus melaksanakan penyuluhan pertanian bagi masyarakat dalam usaha meningkatkan hasil tanaman kakao. 3) Harga kakao lebih tinggi daripada harga kemiri, selain itu harga kakao lebih stabil daripada harga kemiri untuk itu diharapkan agar supaya petani memperhatikan mana lebih tinggi harga kemiri daripada kakao. Untuk itu petani di sarankan lebih baik menanam kakao daripada kemiri agar pendapatan semakin meningkat. 4) Pendapatan petani sebelum menanam kakao masih rendah, untuk itu masyarakat disarankan agar mau berubah dari petani kemiri menjadi petani kakao.

\section{Daftar Pustaka}

Tumpal H.S.Siregar. 2009. Coklat, Pembudidaya, Pengelolaan, Pemasaran. Jakarta; Penebar Swadaya

Timbina Karya Tani. 2008. Pedoman Bertanam Cokelat. Bandung: Yrama Widya

Suratiah,K. 2009. Ilmu Usaha Tani. Jakarta: Penebar Swadaya

Ahmad, 1985. Pertanian Indonesia. Jakarta: Bumi Aksara

Fendy Ruspandi Paimin. 1994. Kemiri, Budidaya dan Prospek Bisnis. Jakarta: Penebar Swadaya

Badan Penelitian dan Perkembangan Pertanian Departemen Pertanian. 2006. Jurnal Penelitian dan Pengembangan Penelitian. Bogor: Badan dan Penelitian dan Pengembangan penelitian.

Cahyono, Bambang Tri. 1992. Masalah Petani Gurem. Yogyakarta: Liberty

Hermanto.1989. Ilmu usaha tani. Jakarta: PT Penebar Swadaya 
Hetty, Yovita. 1993. Pemilihan Tanaman Dan Lahan Sesuai Kondisi Lingkungan dan Pasar. Jakarta : Penebar Swadaya.

Moscher,A.T.1987. Membangun dan Menggerakan Pertanian.

Jakarta: Yasaguna

Mubyarto.1987. Pengantar Ekonomi Pertanian. Jakarta : LP3ES

Mantra Ida Bagus dan Molo Macelius. 1991. Beberapa Masalah

Penduduk di Indonesia dan Akibatnya dibidang Sosial Ekonomi. Prisma

Reintjes.1992. Pertanian Masa Depan. Yogyakarta : Kanisius.

Rukmana, 1994. Pengetahuan Tentang Usaha Tani Indonesia.

Jakarta : Rineka Cipta

Sajogyo.1996. Memahami dan Menanggulangi Kemiskinan di Indonesia. Jakarta : Grafindo

Soekartawi. 1986. Pripsip Dasar Komunikasi Pertanian. Jakarta: Universitas Indonesia (UI Press)

Soekartawi. 1995. Analisis Usaha Tani. Jakarta : Universitas Indonesia (UI Press).

Soetrisno, Loekman. 1999. Pertanian Pada Abad 21. Jakarta: Direktorat Jenderal Pendidikan Tinggi, Departemen Pendidikan dan Kebudayaan.

Suhardiono.1990. Pemanfaatan Lahanpertanian. Jakarta : Departemen Pendidikan dan Kebudayaan.

William, J, Stanton.1994. Prinsip Pemasaran. Jakarta : Erlangga

Suharsimi Asrikunto. 2002. Prosedur Penelitian. Jakarta: Penerbit Rineka Cipta

http://www.serambinews.com/news/view/21375/kemiriprimadona-agara-yang-kian-ditinggalkan, (diakses pukul 22.00.WIB, Senin - 03-Mei - 2010)

Anwas Adiwilaga. 1982. Ilmu Usaha Tani, Bandung: Alumni IKAPI

G.J. VINIK. 1984. Dasar-Dasar Usaha Tani Di Indonesia, Jakarta: Penerbit Yayasan Obor Indonesia. 